BIOFARM

Jurnal Ilmiah Pertanian

ISSN Print: 0216-5430; ISSN Online: 2301-6442

Vol. 14, No. 1, April 2018

\title{
Pengaruh Konsentrasi Pupuk Organik Cair terhadap Pertumbuhan dan Produksi Beberapa Varietas Tanaman Terung (Solanum melongena L)
}

\section{Effect of Liquid Organic Fertilizer Concentration on Growth and Production of Several Eggplant Plant Varieties (Solanum melongena $L$ )}

\author{
Wasis $^{1 *}$ dan Ubad Badrudin ${ }^{2}$ \\ ${ }^{1}$ Dinas Pertanian dan Kehutanan Kabupaten Pemalang \\ ${ }^{2}$ Program Studi Agroteknologi, Fakultas Pertanian, Universitas Pekalongan \\ *Korespondensi Penulis: sis.wasis@yahoo.co.id
}

\begin{abstract}
ABSTRAK
Penelitian ini bertujuan untuk mengetahui konsentrasi pupuk organik cair yang optimal dan varietas yang paling baik serta interaksi antara konsentrasi pupuk organik cair. Penelitian dilakukan di Desa Surajaya Kecamatan Pemalang Kabupaten Pemalang pada ketinggian lebih kurang $10 \mathrm{~m}$ dpl, jenis tanah Alluvial, percobaan dilakukan bulan Juli sampai Oktober 2015. Rancangan percobaan yang digunakan adalah Rancangan Acak Kelompok Lengkap (RAKL) dengan ulangan tiga kali. Faktor pertama konsentrasi pupuk organik cair $(0 ; 7,5 ; 15$; dan $22,5 \mathrm{ml} / \mathrm{l}$ air). Faktor kedua macam varietas (Naga Hijau, Sembrani dan Mustang). Variabel yang diamati meliputi: tinggi tanaman, jumlah cabang per tanaman, saat berbunga, panjang buah, diameter per buah, jumlah buah per tanaman, bobot buah per tanaman, umur saat panen, jumah akar, dan panjang akar terpanjang. Hasil penelitian menunjukkan bahwa konsentrasi pupuk organik cair berpengaruh sangat nyata terhadap semua variabel yang diamati, kecuali saat berbunga dan umur saat panen tidak berbeda nyata. Pertumbuhan dan produksi tanaman terung tertinggi diperoleh pada konsentrasi $22,5 \mathrm{ml} / \mathrm{l}$ air. Macam varietas berpengaruh sangat nyata terhadap semua variabel yang diamati, kecuali saat berbunga dan umur saat panen. Pertumbuhan dan produksi tertinggi diperoleh pada varietas Mustang. Terdapat interaksi antara konsentrasi pupuk organik cair dengan macam varietas terhadap bobot buah per tanaman. Konsentrasi pupuk organik cair 22,5 ml/l air dengan varietas Mustang menunjukkan hasil yang terbaik.
\end{abstract}

Kata kunci: terung, konsentrasi, pupuk organik cair, varietas.

\begin{abstract}
This research aims to know the concentration optimal liquid organic fertilizer and the most excellent varieties as well as the interaction between the concentration of liquid organic fertilizer with a range of varieties and crop production towards growth of Eggplant. Research conducted in the village of Pemalang Regency of Pemalang Surajaya Sub at a height of approximately $10 \mathrm{~m}$ above sea level, the soil type Alluivial, an experiment was conducted during a four-month i.e. July to October 2015. The experimental design used was Randomized Complete Design Group (RAKL). First factor was the concentration of liquid organic fertilizer ( $0 ; 7.5 ; 15$; and $22.5 \mathrm{ml} / \mathrm{l}$ of water). The second factor is the assortment of varieties (the Green Dragon, Sembrani and Mustang). The variables measured include: plant height, number of branches per plant , when in flower, fruit length, diameter per fruit, number of fruit per plant, fruit weight per plant, the age at harvest, the sheer number of roots, and the length of the longest root. The results showed that the concentration of organic liquid fertilizer very significant effect on all observed variables, except age during flowering and harvest time. Growth and yield of eggplant obtained at the highest concentration of $22.5 \mathrm{ml} / \mathrm{I}$ of water. A wide variety of very significant effect on all observed variables, except age during flowering and harvest time. Growth and the highest production was obtained on a variety of Mustang. There is no interaction between the concentration of liquid organic fertilizer with a wide variety of the fruit weight per plant. The concentration of liquid organic fertilizer $22.5 \mathrm{ml} /$ l of water with varieties of Mustang show the best results.
\end{abstract}

Keywords: eggplants, concentration, organic liquid fertilizer, variety.

\section{PENDAHULUAN}

Tanaman terung termasuk salah satu sayur-sayuran, di dalam kehidupan seharihari buah terung dapat digunakan sebagai sayur lodeh, opor, lalap segar atau pun lalap masak karena cita rasanya yang enak. Selain itu dapat juga dibuat terung asinan dan manisan. Dalam dunia kesehatan terung dikenal sebagai penurun kolesterol darah, mengandung zat anti kanker, serta alat kontrasepsi (htpp://agrobisndo.com). Buah terung mengandung gizi yang cukup tinggi yaitu dalam setiap $100 \mathrm{~g}$ buah terung segar mengandung sebanyak 24 kalori, 1,1 g protein, 0,2 g lemak, $5,5 \mathrm{~g}$ karbohidrat, $15 \mathrm{mg}$ kalsium, 37 $\mathrm{mg}$ fosfor, $0,4 \mathrm{mg}$ besi, $4 \mathrm{SI}$ vitamin $\mathrm{A}, 5 \mathrm{mg}$ 
vitamin $\mathrm{C}, 0,04 \mathrm{mg}$ vitamin $\mathrm{B} 1$, dan $92,7 \mathrm{~g}$ air. Kadar kalium yang tinggi dan natrium yang rendah sangat menguntungkan bagi kesehatan khususnya dalam pencegahan penyakit hipertensi (Sakri, 2012).

Secara ekonomi, terung merupakan komoditi sayuran yang dapat diandalkan. Didukung dengan tingginya permintaan dan daya beli masyarakat serta harga jual yang cukup tinggi, terung dapat dijadikan komoditi yang menjanjikan. Permintaan masyarakat akan terung terus meningkat dari waktu ke waktu. Hal tersebut ditunjukkan dengan semakin meluasnya daerah pemasaran (Cahyono, 2003).

Produksi terung di Indonesia mulai tahun 2003-2012 mengalami peningkatan. Pada tahun 2003 produksi buah terung sebesar 301.030 ton, tahun 2004 meningkat menjadi 312.354 ton, kemudian tahun 2008 makin meningkat menjadi 427.166 ton dan pada tahun-tahun berikutnya meningkat hingga tahun 2012 meningkat sampai 518.827 ton (Badan Pusat Statistik, 2012).

Permintaan masyarakat akan terung terus meningkat dari waktu ke waktu, hal tersebut ditunjukkan makin meluasnya daerah pemasaran, tidak hanya dijumpai di supermarket-supermarket terkenal, saat ini rumah makan dan hotel-hotel besar pun banyak menjadikan terung sebagai salah satu menu makannya, sehingga produksi terung harus ditingkatkan dan diperhatikan, karena mempunyai nilai ekonomis yang cukup tinggi dan telah mampu menerobos pasaran ekspor terutama ke negara Jepang maka tanaman ini berpotensi untuk dikembangkan (Samadi, 2003).

Usaha untuk meningkatkan produksi dan kualitas terung guna memenuhi permintaan pasar sekarang ini dapat ditempuh melalui 2 cara, yaitu secara ekstensifikasi dan intensifikasi. Upaya peningkatan produksi terung dengan cara ekstensifikasi (memperluas areal pertanaman) sudah tidak efektif lagi karena lahan pertanian yang semakin sempit, keadaan beralih fungsi menjadi lahan -lahan pemukiman warga atau perumahan dan kawasan industri. Usaha yang mungkin dilakukan untuk meningkatkan produksi dan kualitas terung, yaitu dengan cara intensifikasi pertanian, yaitu dengan cara meningkatkan teknologi yang ditempuh untuk meningkatkan produksi dan kualitas terung dengan cara melakukan pemupukan (Rukmana, 2002).

Menurut Sarief (2002) pemupukan adalah usaha memberikan pupuk agar unsur hara dapat tersedia sesuai dengan kebutuhan tanaman. Pemupukan yang biasa dilakukan petani adalah pemberian pupuk ke dalam tanah, namun pemberian pupuk ke dalam tanah tersebut kadang-kadang kurang efektif karena beberapa unsur hara harus larut terlebih dahulu dan dapat hilang bersama air perkolasi atau mengalami pengikatan oleh koloid tanah sehingga tidak dapat diserap oleh tanaman. Upaya yang dapat dilakukan agar pemupukan lebih efektif dan efisien adalah dengan pemupukan melalui tubuh tanaman terutama daun, salah satunya adalah dengan pupuk organik cair.

Menurut Hadisuwito (2007) pupuk organik cair adalah larutan dari hasil pembusukan bahan-bahan organik yang berasal dari sisa tanaman, kotoran hewan dan manusia yang kandungan unsur haranya lebih dari satu unsur. Kelebihan dari pupuk organik cair adalah dapat secara cepat mengatasi defisiensi hara, tidak bermasalah dalam pencucian hara, dan menyediakan hara secara cepat. Pupuk organik cair tidak merusak humus tanah walaupun seringkali digunakan, selain itu pupuk organik cair memiliki zat pengikat larutan hingga bisa langsung digunakan pada tanah tidak butuh interval waktu untuk dapat menanam tanaman. Pupuk organik cair dapat memberikan hara yang sesuai dengan kebutuhan tanaman pada tanah, karena bentuknya cair, maka jika terjadi kelebihan kapasitas pupuk pada tanah maka dengan sendirinya tanaman akan mudah mengatur penyerapan komposisi pupuk yang dibutuhkan (http://kamalhijau.blogspot.com). Salah satu contoh pupuk organik cair yang biasa digunakan adalah pupuk organik cair Nasa.

Pupuk pada umumnya diberikan de- 
ngan ditabur atau dibenamkan dalam tanah, pupuk juga dapat diberikan dengan disemprotkan pada tanaman, seperti pupuk organik cair. Pupuk organik cair adalah pupuk yang kandungan bahan kimianya 5\% karena itu kandungan NPK pupuk organik cair relatif rendah. Namun pupuk organik cair mempunyai beberapa keuntungan yaitu pupuk organik cair mengandung zat tertentu seperti mikroorganisme yang jarang terdapat pada pupuk organik padat. Pada bentuk kering beberapa mikroorganisme mati dan zat tidak bisa aktif, jika dicampur dengan pupuk organik padat, pupuk organik cair dapat mengaktifkan unsur hara yang ada dalam pupuk organik padat (Parnata, 2005).

Pemberian pupuk organik cair melalui daun memberikan pertumbuhan dan hasil tanaman yang lebih baik dari pada pemberian melalui tanah. Semakin tinggi konsentrasi pupuk yang diberikan maka kandungan unsur hara yang diterima oleh tanaman akan semakin tinggi, begitu pula dengan semakin seringnya frekuensi aplikasi pupuk daun yang dilakukan pada tanaman, maka kandungan unsur hara juga semakin tinggi. Namun, pemberian dengan konsentrasi yang berlebihan justru akan mengakibatkan timbulnya gejala kelayuan pada tanaman (Rizqiani, 2007). Menurut Harahap (2005) pemberian pupuk organik cair dengan konsentrasi $15 \mathrm{ml} /$ liter air memberikan pertumbuhan dan hasil terung terbaik.

Selain penggunaan pupuk organik cair, produksi terung juga dipengaruhi oleh varietas yang digunakan. Menurut Rukmana (2002) daya hasil tanaman terung sangat dipengaruhi oleh varietas dan tingkat adaptasi terhadap keadaan lingkungan. Karnomo dkk., (1990) menyatakan bahwa daya hasil atau produksi dapat ditingkatkan dengan pemakaian varietas yang cocok dengan lingkungan dan mempunyai daya hasil tinggi. Lebih lanjut dikatakan bahwa, setiap varietas mempunyai potensi daya hasil yang berbedabeda dan mempunyai kemampuan untuk beradaptasi dengan lingkungan yang berbeda pula, sehingga perlu dilakukan pengujian terhadap masing-masing varietas untuk men- dapatkan hasil yang maksimal.

Dari beberapa fenomena di atas dalam penelitian ini perlu dipecahkan beberapa permasalahan antara lain: 1) Berapa konsentrasi pupuk organik cair yang optimal untuk meningkatkan pertumbuhan dan produksi terung, 2) Varietas terung manakah yang paling baik untuk pertumbuhan dan produksi terung , 3) Apakah terdapat interaksi antara konsentrasi pupuk organik cair dengan macam varitas terhadap pertumbuhan dan produksi terung.

Adapun Penelitian ini dilakukan dengan tujuan untuk: 1) Mengetahui konsentrasi pupuk organik cair yang optimum terhadap peningkatan pertumbuhan dan produksi terung, 2) Mengetahui varietas terung yang paling baik terhadap peningkatan pertumbuhan dan produksi terung. 3) Mengetahui interaksi antara konsentrasi pupuk organik cair dengan varietas terung terhadap peningkatan pertumbuhan dan produksi terung.

\section{BAHAN DAN METODE}

Percobaan telah dilaksanakan di Desa Surajaya Kecamatan Pemalang Kabupaten Pemalang pada ketinggian 10 meter di atas permukaan laut, selama empat bulan yaitu Juli sampai dengan bulan Oktober 2015. Rancangan percobaan yang digunakan adalah Rancangan Acak Kelompok Lengkap (RAKL) dengan perlakuan faktorial $4 \times 3$. Faktor pertama konsentrasi pupuk organik cair yang terdiri atas 4 taraf, yaitu tanpa pupuk organik cair, $7,5 \mathrm{ml} / \mathrm{l}$ air, $15 \mathrm{ml} / \mathrm{I}$ air, dan $22,5 \mathrm{ml} / \mathrm{l}$ air. Faktor kedua macam varietas terdiri atas 3 taraf, yaitu Naga Hijau, Sembrani, dan Mustang. Dengan demikian terdapat 12 kombinasi perlakuan, masingmasing perlakuan diulang tiga kali sehingga seluruhnya ada $(4 \times 3) \times 3=36$ satuan percobaan.

Data yang dihasilkan dianalisis dengan uji $\mathrm{F}$ dan apabila terdapat perbedaan diantara faktor yang dicoba, maka analisis dilanjutkan dengan uji BNT dan uji regresi. Khusus untuk macam varietas dengan uji kontras orthogonal.

Variabel yang diamati meliputi: 
tinggi tanaman, (2) Jumlah cabang per tanaman, (3) saat berbunga, (4) panjang buah, (5) diameter per buah, (6) jumlah buah per tanaman, (7) bobot buah per tanaman, (8) umur saat panen, (9) jumlah akar, (10) panjang akar terpanjang.

\section{HASIL DAN PEMBAHASAN}

\section{Pengaruh konsentrasi pupuk organik cair}

Hasil penelitian menunjukkan bahwa konsentrasi pupuk organik cair berpengaruh sangat nyata terhadap pertumbuhan dan hasil tanaman terung. Pertumbuhan dan hasil tertinggi dicapai pada konsentrasi $22,5 \mathrm{ml} / \mathrm{l}$ air dan terendah pada konsentrasi $0 \mathrm{ml} / \mathrm{l}$ air, artinya makin tinggi konsentrasi pupuk organik cair dapat meningkatkan pertumbuhan dan hasil. Hal ini disebabkan pemberian pupuk organik cair pada konsentrasi $22,5 \mathrm{ml} / \mathrm{l}$ dapat memacu pembelahan dan pemanjangan sel seperti pada batang, akar dan daun yang menyebabkan meningkatnya pertumbuhan dan hasil tanaman terung dan pada konsentrasi $22,5 \mathrm{ml} / \mathrm{l}$ masih dapat ditingkatkan lagi.

Tabel 1. Angka rata-rata dan Analisis Statistik Data Penelitian Pengaruh Konsentrasi Pupuk Organik Cair terhadap Pertumbuhan dan Produksi Beberapa Varietas Tanaman Terung (Solanu melongena L.).

\begin{tabular}{|c|c|c|c|c|c|}
\hline Perlakuan & $\begin{array}{l}\text { Tinggi } \\
\text { tanaman } \\
(\mathrm{cm})\end{array}$ & $\begin{array}{l}\text { Jumlah cabang per } \\
\text { tanaman } \\
\text { (batang) }\end{array}$ & $\begin{array}{l}\text { Saat } \\
\text { berbunga } \\
\text { (hst) }\end{array}$ & $\begin{array}{l}\text { Panjang } \\
\text { buah } \\
\text { (cm) }\end{array}$ & $\begin{array}{l}\text { Diameter } \\
\text { buah } \\
(\mathrm{cm})\end{array}$ \\
\hline \multicolumn{6}{|l|}{ Konsentrasi POC } \\
\hline $\mathrm{K} 0=0 \mathrm{ml} / \mathrm{l}$ air & $42,71 \mathrm{a}$ & $2,16 \mathrm{a}$ & $56,78 \mathrm{a}$ & 15,94 a & $5,10 \mathrm{a}$ \\
\hline $\mathrm{K} 1=7,5 \mathrm{ml} / \mathrm{l}$ air & $45,82 \mathrm{~b}$ & $2,16 \mathrm{~b}$ & $57,00 \mathrm{a}$ & $16,11 \mathrm{ab}$ & $5,27 a b$ \\
\hline $\mathrm{K} 2=15 \mathrm{ml} / \mathrm{l}$ air & $48,04 \mathrm{bc}$ & $2,31 \mathrm{c}$ & $57,00 \mathrm{a}$ & $16,33 \mathrm{~b}$ & $5,54 \mathrm{bc}$ \\
\hline $\mathrm{K} 3=22,5 \mathrm{ml} / \mathrm{l}$ air & $49,09 \mathrm{c}$ & $2,49 c$ & $58,22 \mathrm{a}$ & $17,28 \mathrm{c}$ & $5,99 \mathrm{c}$ \\
\hline F hitung & $8,76^{* *}$ & $5,72^{\star *}$ & $0,89^{\star *}$ & $8,39^{* *}$ & $9,01^{* *}$ \\
\hline$F$ tabel $5 \%$ & 3,05 & 3,05 & 3,05 & 3,05 & 3,05 \\
\hline $\mathrm{F}$ tabel $1 \%$ & 4,63 & 4,63 & 4,63 & 4,63 & 4,63 \\
\hline BNT 5\% & 2,80 & 0,19 & - & 0,60 & 0,38 \\
\hline KK (\%) & 6,16 & 8,74 & 3,64 & 3,76 & 7,07 \\
\hline \multicolumn{6}{|l|}{ Macam Varietas } \\
\hline V1 = Naga Hijau & $16,69 \mathrm{~b}$ & $2,15 \mathrm{a}$ & $56,17 \mathrm{a}$ & $15,50 \mathrm{a}$ & $5,14 a$ \\
\hline V2 = Sembrani & $14,99 \mathrm{a}$ & $2,28 a b$ & $57,50 \mathrm{a}$ & $16,59 \mathrm{~b}$ & $5,53 \mathrm{~b}$ \\
\hline V3 = Mustang & $14,30 \mathrm{a}$ & $2,40 \mathrm{~b}$ & $58,80 \mathrm{a}$ & $17,06 \mathrm{~b}$ & $5,76 b$ \\
\hline F hitung & $19,22^{\star \star}$ & $4,74^{\star}$ & $2,67 \mathrm{tn}$ & $17,49^{\star *}$ & $7,97^{\star \star}$ \\
\hline$F$ tabel $5 \%$ & 3,44 & 3,44 & 3,44 & 3,44 & 3,44 \\
\hline $\mathrm{F}$ tabel $1 \%$ & 5,72 & 5,72 & 5,72 & 5,72 & 5,72 \\
\hline BNT 5\% & 0,82 & 0,17 & - & 0,52 & 0,33 \\
\hline KK $(\%)$ & 6,35 & 8,74 & 3,64 & 3,76 & 7,07 \\
\hline
\end{tabular}

Keterangan :

Angka-angka dalam kolom dan perlakuan yang diikuti dengan huruf yang sama menunjukkan tidak berbeda nyata berdasarkan uji BNT Pada taraf $5 \% .{ }^{*}=$ berbeda nyata, ${ }^{* *}=$ berbeda sangat nyata.

Lingga (2008) menyatakan bahwa pupuk organik cair antara lain mengandung unsur hara makro $\mathrm{N}, \mathrm{P}$, dan $\mathrm{K}$ yang mempunyai peranan penting untuk pertumbuhan dan perkembangan tanaman. Peranan unsur $\mathrm{N}$ bagi tanaman adalah meningkatkan pembentukan klorofil, sintesis asam amino dan protein. Meningkatnya jumlah klorofil akan meningkatkan laju fotosintesis sehingga fotosintat yang dihasilkan juga meningkat. Fotosintat tersebut selanjutnya digunakan untuk pertumbuhan vegetatif tanaman (Sarief,
2002). Menurut Karnomo dkk., (1990) unsur $\mathrm{P}$ mempunyai peranan yang penting dalam pembentukan akar, unsur $P$ bersama-sama dengan unsur $\mathrm{N}$ dapat mendorong pembentukan akar dan rambut-rambut akar sehingga tanaman dapat menyerap unsur hara secara maksimal. Kondisi demikian akan berpengaruh terhadap meningkatnya pertumbuhan tanaman. Peranan Kalium adalah (1) sebagai katalisator dan stimulan dari beberapa proses fosforilasi, (2) proses metabolisme karbohidrat, dan (3) mengaktifkan enzim. 
Dilihat dari peranan dan fungsi unsur hara yang terkandung di dalam pupuk organik cair tersebut, maka pemberian pupuk organik cair dalam jumlah maksimum dapat meningkatkan pertumbuhan vegetatif maupun generatif tanaman. Harjadi (2003) menyatakan bahwa ketersediaan unsur hara dalam jumlah yang cukup dan seimbang yang didukung oleh lingkungan menguntungkan maka pertumbuhan tanaman akan lebih baik dan proses fotosintesis berlang- sung dengan lancar sehingga meningkatkan asimilat yang selanjutnya dimanfaatkan oleh tanaman untuk pertumbuhan dan pembentukan buah. Oleh karena itu makin banyak asimilat yang digunakan untuk pertumbuhan dan sebagai bahan pensuplai pembentukan buah, maka pertumbuhan menjadi meningkat dan buah yang terbentuk menjadi lebih banyak serta mempunyai bobot yang lebih besar.

Tabel 2. Angka rata-rata dan Analisis Statistik Data Penelitian Pengaruh Konsentrasi Pupuk Organik Cair terhadap Pertumbuhan dan Produksi Beberapa Varietas Tanaman Terung (Solanu melongena L.).

\begin{tabular}{|c|c|c|c|c|c|}
\hline Perlakuan & $\begin{array}{l}\text { Jumlah buah } \\
\text { per tanaman } \\
(\mathrm{kg})\end{array}$ & $\begin{array}{l}\text { Bobot buah per } \\
\text { tanaman } \\
(\mathrm{kg})\end{array}$ & $\begin{array}{l}\text { Umur saat } \\
\text { panen } \\
\text { (hst) }\end{array}$ & $\begin{array}{l}\text { Jumlah } \\
\text { akar } \\
\text { (buah) }\end{array}$ & $\begin{array}{l}\text { Panjang } \\
\text { akar } \\
\text { (cm) }\end{array}$ \\
\hline \multicolumn{6}{|l|}{ Konsentrasi POC } \\
\hline $\mathrm{K} 0=0 \mathrm{ml} / \mathrm{l}$ air & $2,04 \mathrm{a}$ & $0,78 \mathrm{a}$ & $100,33 \mathrm{a}$ & $13,11 \mathrm{a}$ & $35,72 \mathrm{a}$ \\
\hline $\mathrm{K} 1=7,5 \mathrm{ml} / \mathrm{l}$ air & $2,20 a b$ & $0,88 a b$ & $100,44 a$ & $14,13 \mathrm{ab}$ & $37,27 a b$ \\
\hline $\mathrm{K} 2=15 \mathrm{ml} / \mathrm{l}$ air & $2,31 \mathrm{bc}$ & $0,95 \mathrm{~b}$ & $100,56 a$ & $15,58 \mathrm{~b}$ & $39,49 \mathrm{bc}$ \\
\hline $\mathrm{K} 3=22,5 \mathrm{ml} / \mathrm{l}$ air & $2,42 \mathrm{c}$ & $1,12 \mathrm{c}$ & $101,67 \mathrm{a}$ & $17,40 \mathrm{c}$ & $41,27 \mathrm{c}$ \\
\hline F hitung & $5,45^{\star *}$ & $19,27^{\star *}$ & 1,72 tn & $9,88^{* *}$ & $9,85^{\star *}$ \\
\hline $\mathrm{F}$ tabel $5 \%$ & 3,05 & 3,05 & 3,05 & 3,05 & 3,05 \\
\hline $\mathrm{F}$ tabel $1 \%$ & 4,63 & 4,63 & 4,63 & 4,63 & 4,63 \\
\hline BNT 5\% & 0,09 & 0,09 & - & 1,74 & 2,44 \\
\hline KK (\%) & 9,23 & 10,40 & 1,40 & 11,80 & 6,52 \\
\hline \multicolumn{6}{|l|}{ Macam Varietas } \\
\hline V1 = Naga Hijau & $2,08 \mathrm{a}$ & $0,83 a$ & $100,17 \mathrm{a}$ & $12,95 \mathrm{a}$ & $35,68 \mathrm{a}$ \\
\hline V2 = Sembrani & $2,20 a$ & $0,93 a$ & $100,75 a$ & $15,32 b$ & $38,08 \mathrm{~b}$ \\
\hline V3 = Mustang & $2,45 b$ & $1,03 \mathrm{c}$ & $101,33 a$ & $16,90 \mathrm{c}$ & $41,20 \mathrm{c}$ \\
\hline F hitung & $9,81^{* *}$ & $13,03^{\star *}$ & $2,05 \mathrm{tn}$ & $15,01^{* *}$ & $14,72^{\star *}$ \\
\hline $\mathrm{F}$ tabel $5 \%$ & 3,44 & 3,44 & 3,44 & 3,44 & 3,44 \\
\hline F tabel $1 \%$ & 5,72 & 5,72 & 5,72 & 5,72 & 5,72 \\
\hline BNT 5\% & 0,18 & 0,08 & - & 1,51 & 2,11 \\
\hline KK (\%) & 9,23 & 10,40 & 1,40 & 11,80 & 6,52 \\
\hline
\end{tabular}

Keterangan :

Angka-angka dalam kolom dan perlakuan yang diikuti dengan huruf yang sama menunjukkan tidak berbeda nyata berdasarkan uji BNT Pada taraf $5 \%$. * = berbeda nyata, ${ }^{* *}=$ berbeda sangat nyata.

\section{Pengaruh macam varietas}

Hasil penelitian menunjukkan bahwa macam varietas berpengaruh sangat nyata terhadap jumlah buah per tanaman dan bobot buah per tanaman. Varietas Mustang memberikan hasil yang tertinggi dibanding varietas Sembrani, sedangkan hasil terendah pada varietas Naga Hijau. Perbedaan yang sangat nyata ini disebabkan varietas Mustang mempunyai sistem perakaran yang lebih baik dibanding varietas Sembrani maupun Naga Hijau sehingga penyerapan unsur hara lebih baik dan maksimal, akibatnya proses metabolisme dapat berlangsung dengan sempurna.
Jumin (2001) menyatakan bahwa tanaman yang mempunyai sistem perakaran yang lebih baik dapat melakukan penyerapan unsur hara dan air lebih maksimal, akibatnya proses metabolisme tanaman dapat berlangsung dengan sempurna dan asimilat meningkat. Asimilat tersebut selanjutnya ditranslokasikan ke seluruh bagian tanaman untuk pertumbuhan dan sisanya digunakan untuk pembentukan buah, oleh karena itu makin banyak asimilat yang digunakan untuk pembentukan buah, makin tinggi jumlah dan bobot buah yang terbentuk. Pendapat ini didukung oleh Sarief (2002) yang menyatakan bahwa me- 
ningkatnya pertumbuhan tanaman akan meningkatkan serapan unsur hara, maka kebutuhan hara bagi tanaman lebih terpenuhi dan metabolisme menjadi lebih baik sehingga pembentukan karbohidrat, protein dan lemak tidak terhambat, akibatnya akumulasi bahan hasil metabolisme pada buah meningkat, akibatnya berpengaruh terhadap meningkatnya jumlah dan bobot buah per tanaman.

Tabel 3. Pengaruh Interaksi antara Konsentrasi Pupuk Organik Cair dan Macam Varitas terhadap Bobot Buah per Tanaman.

\begin{tabular}{ll}
\hline $\begin{array}{l}\text { Kombinasi } \\
\text { Perlakuan }\end{array}$ & $\begin{array}{l}\text { Bobot buah per tanaman } \\
(\mathrm{kg})\end{array}$ \\
\hline K0V1 & $0,65 \mathrm{a}$ \\
K0V2 & $0,86 \mathrm{ab}$ \\
K0V3 & $0,84 \mathrm{ab}$ \\
K1V1 & $0,79 \mathrm{ab}$ \\
K1V2 & $0,87 \mathrm{ab}$ \\
K1V3 & $0,97 \mathrm{abc}$ \\
K2V1 & $0,95 \mathrm{abc}$ \\
K2V2 & $0,92 \mathrm{ab}$ \\
K2V3 & $0,97 \mathrm{abc}$ \\
K3V1 & $0,92 \mathrm{ab}$ \\
K3V2 & $1,09 \mathrm{bc}$ \\
K3V3 & $1,35 \mathrm{c}$ \\
F hitung & $2,89 * *$ \\
F tabel 5\% & 2,55 \\
F tabel 1\% & 3,76 \\
BNT 5\% & 0,40 \\
KK (\%) & 10,40 \\
\hline Keterngan &
\end{tabular}

Keterangan :

Angka-angka dalam kolom dan perlakuan yang diikuti dengan huruf yang sama menunjukkan tidak berbeda nyata berdasarkan uji BNT Pada taraf $5 \% .{ }^{*}=$ berbeda nyata, ${ }^{* *}=$ berbeda sangat nyata

\section{Pengaruh interaksi antara konsentrasi pupuk organik cair dengan macam varietas}

Hasil penelitian menunjukkan bahwa interaksi antara konsentrasi pupuk organik cair dengan macam varietas berbeda nyata terhadap bobot buah per tanaman. Interaksi terbaik diperoleh pada konsentrasi pupuk organik cair $22,5 \mathrm{ml} / \mathrm{l}$ air dengan varietas Mustang (K3V3) yang menghasilkan bobot buah per tanaman rata-rata $1,35 \mathrm{~kg}$, sedangkan hasil terendah pada konsentrasi konsentrasi pupuk organik $0 \mathrm{ml} / \mathrm{l}$ air atau tanpa pupuk organik cair dengan varietas Naga Hijau (KOV1) yang itu 0,65 kg.

Interaksi ini terjadi karena adanya saling mendukung antara nutrisi yang terkan- dung dalam pupuk organik cair pada konsentrasi $22,5 \mathrm{ml} / \mathrm{l}$ air dengan kandungan yang lebih banyak dan seimbang yang dapat menyediakan unsur hara bagi tanaman dan varietas Mustang mempunyai tingkat adaptasi dan penyerapan unsur hara yang lebih baik sehingga laju pertumbuhan tanaman akan lebih maksimal, maka tanaman dapat melakukan metabolisme secara sempurna. Hakim dkk., (2000) menyatakan bahwa proses metabolisme tanaman sangat dipengaruhi oleh ketersediaan unsur hara, sinar matahari, dan air yang dapat dimanfaatkan oleh tanaman. Apabila ketersediaan unsur hara, air, sinar matahari cukup maka metabolisme akan berjalan dengan lancar sehingga bahan yang dihasilkan untuk membentuk buah seperti protein, dan karbohidrat akan meningkat. $\mathrm{Hal}$ ini akan berpengaruh terhadap pembentukan buah, selanjutnya akan berpengaruh pula terhadap pembentukan buah, oleh karena itu makin banyak protein dan karbohidrat yang dihasilkan makin meningkat pula buah yang terbentuk, sehingga berpengaruh terhadap bobot buah per tanaman (Soepardi, 2008).

\section{KESIMPULAN}

1. Konsentrasi pupuk organik cair berpengaruh sangat nyata terhadap semua variabel yang diamati, kecuali saat berbunga dan umur saat panen dengan pola pengaruh bersifat linier positif. Pertumbuhan dan produksi terung tertinggi diperoleh pada konsentrasi $22,5 \mathrm{ml} / \mathrm{l}$ air.

2. Macam varietas berpengaruh sangat nyata terhadap tinggi tanaman, panjang buah, diameter per buah, jumlah buah per tanaman, bobot buah per tanaman, jumlah akar, dan panjang akar trepanjang, berbeda nyata terhadap jumlah cabang per tanaman dan tidak berbeda nyata terhadap saat berbunga dan umur saat panen. Pertumbuhan dan produksi terung tertinggi diperoleh pada varietas Mustang.

3. Interaksi antara konsentrasi pupuk organik cair dengan macam varietas tidak berbeda nyata terhadap semua variabel yang diamati kecuali bobot buah per tanaman berbeda nyata. Konsentrasi pupuk organik cair 22,5 ml/l air dengan varietas Mustang menunjukkan hasil yang terbaik. 
DAFTAR PUSTAKA

Anton. 2003. Pupuk Organik Cair Lengkap (POCL) Super ACl, Makasar. Badan Pusat Statistik. 2012. Statistik Indonesia. Jakarta.

Cahyono, B. 2003. Teknik Strategi Budidaya Terung. Yayasan Pustaka Nusatama. Yogyakarta.

Hadisuwito. 2007. Membuat Pupuk Kompos Cair. Agromedia Pustaka. Jakarta. 50 Hal.

Hakim, N., M. Yusuf, Nyakpa, Sutopo, G., A.M. Lubis, M. Rusdi, Amin, D., Go BangHong dan H. Bailey. 2000. Dasar-dasar IImu Tanah. Universitas Lampung, Lampung.

Harjadi, S.S. 2003. Pengatar Agronomi. Gramedia, Jakarta.

Hastuti. 2007. Terung. Fakultas Matematika dan Ilmu Pengetahuan Alam. Universitas Sumatera Utara.

https://Imgaagro.wordpress.com/2014/05/04/ budidaya-tanaman-terong-yang-baikdan- benar/. Diakses tanggal 26 Pebruari 2015.

Jumin. 2001. Agronomi. Raja Grafindo Persada, Jakarta.

Karnomo, Soemedi, Dewanto, Widhiatmoko, Amirudin, Agusnirwanto. 1990. Pengantar Produksi Tanaman Agronomi. Fakulas Pertanian
Universitas Jenderal Soedirman. Purwokerto.

Lingga, P. 2008. Petunjuk Penggunaan Pupuk. Penebar Swadaya. Jakarta.

Parnata A.S. 2005. Pupuk Organik Cair, Aplikasi dan Manfaatnya. PT. agromedia Pustaka. Depok.

Prihmantoro. 2002. Memupuk Tanaman Sayur. Penebar Swadaya, Jakarta.

Rizqiani N,F. dkk. 2007. Pengaruh Konsentrasi dan Frekuensi Pemberian Pupuk Organik Cair dan Hasil Buncis (Pheassoles Vulgacis L.) Pada Dataran Rendah.Jurnal IImu Tanah dan Lingkungan. Yogyakarta.

Rukmana, 1994.Bertanam Persai dan Sawi.Kasinus. Yogyakarta.

Rukmana, 2002. Bertanam Terung. Kanisius, Yogyakarta. Samadi. 2003. Budidaya Terung Hibrida. Kanisius. Yogyakarta.

Sakri, R.M. 2012. Meraup Untung Jutaan Rupiah dari Budidaya Terung Putih. Penebar Swadaya. Jakarta.

Sarief. 2002. Kesuburan dan Pemupukan Tanah Pertanian. Pustaka Buana, Bandung.

Soepardi, G. 2008. Masalah Kesuburan Tanah dan Pupuk. Departemen IImu Tanah IPB, Bogor. 